\title{
Establishing a high throughput method for medium optimization - a case study using Streptomyces lividans as host for production of heterologous protein
}

\author{
Rattleff, Stig; Thykaer, Jette; Lantz, Anna Eliasson
}

Published in:

New Biotechnology

Link to article, DOI:

10.1016/j.nbt.2012.08.139

Publication date:

2012

Document Version

Publisher's PDF, also known as Version of record

Link back to DTU Orbit

Citation (APA):

Rattleff, S., Thykaer, J., \& Lantz, A. E. (2012). Establishing a high throughput method for medium optimization a case study using Streptomyces lividans as host for production of heterologous protein. New Biotechnology, 29S, S50. https://doi.org/10.1016/j.nbt.2012.08.139

\section{General rights}

Copyright and moral rights for the publications made accessible in the public portal are retained by the authors and/or other copyright owners and it is a condition of accessing publications that users recognise and abide by the legal requirements associated with these rights.

- Users may download and print one copy of any publication from the public portal for the purpose of private study or research.

- You may not further distribute the material or use it for any profit-making activity or commercial gain

- You may freely distribute the URL identifying the publication in the public portal 


\section{Poster 1.2.05}

Use of aerobic/anaerobic system for nutrient removal (C, $N$, P) in dairy wastewater plant: application of RSM in batch conditions

Malihe Amini ${ }^{1, *}$, Habibollah Younesi ${ }^{1}$, Ghasem Najafpour ${ }^{2}$, Ali Akbar Zinatizadeh Lorestani ${ }^{3,4}$

${ }^{1}$ Department of Environmental, Faculty of Natural Resources, Tarbiat Modarres University, Imam Reza Street, P.O. Box: 46414-356, Noor, Iran

${ }^{2}$ Department of Chemical Engineering, Engineering Faculty, University of Mazandaran, Babol, Iran

${ }^{3}$ Department of Applied Chemistry, Faculty of Chemistry, Razi University, Kermanshah, Iran

${ }^{4}$ Water and Wastewater Research Center (WWRC), Razi University, Kermanshah, Iran

The batch systems appears today as a robust technology and is widely used for dairy wastewater treatment. Combined (anaerobic/aerobic) biological treatment methods for simultaneous removal of carbon, nitrogen and phosphors are discussed. The experimental design was face centered-central composite design (FC-CCD) with four operational variables (MLSS, COD:N:P ratio, aeration time and cycling time). Nine dependent parameters as the process responses were studied. The removal efficiency of COD, TKN, $\mathrm{PO}_{4}{ }^{3-}, \mathrm{NO}_{3}{ }^{-}$and amount of SVI, MLSS, MLVSS, effluent $\mathrm{NO}_{3}{ }^{-}$and effluent TN were 98.95\%, 85.6\%, 98.34\%, $99.99 \%, 44.03 \mathrm{ml} / \mathrm{g}, 5646.97 \mathrm{mg} / \mathrm{l}, 4435.99 \mathrm{mg} / \mathrm{l}, 0.03 \mathrm{mg} / \mathrm{l}$ and $56.55 \mathrm{mg} / \mathrm{l}$, respectively. At last, the optimum conditions for nutrients removal were found to be a level of desirability of 0.995 at MLSS $4499.84 \mathrm{mg} / \mathrm{l}$, COD:N:P ratio 100:24.98:9, Aeration time $40 \mathrm{~min} / \mathrm{h}$ and cycling time $30.11 \mathrm{~h}$. At these optimized conditions, responses were shown: COD 88.44\%, TKN 70\%, $\mathrm{PO}_{4}{ }^{3-}$ $87.41 \%, \mathrm{NO}_{3}{ }^{-} 82.22 \%, \mathrm{NO}_{3}{ }^{-}$effluent $1.81 \mathrm{mg} / \mathrm{l}$ and $\mathrm{TN}$ effluent $76.81 \mathrm{mg} / \mathrm{l}$, respectively. These results suggest significant promise of this approach for application to wastewater with high nitrogen, phosphors and carbon content in dairy wastewater plants.

Keywords: Nutrient removal percentage; Dairy wastewater treatment; Batch systems; RSM; Optimization

http://dx.doi.org/10.1016/j.nbt.2012.08.137

Poster 1.2.06

Benzoic acid fermentation from starch and cellulose via a plant-like $\beta$-oxidation pathway in Streptomyces maritimus

Shuhei Noda*, Tsutomu Tanaka, Chiaki Ogino, Akihiko Kondo

Department of Chemical Science and Engineering, Graduate School of Engineering, Kobe University, 1-1 Rokkodai, Nada, Kobe 657-8501, Japan

Benzoic acid is one of the most useful aromatic compounds. Despite its versatility and simple structure, benzoic acid production using microbes has not been reported previously. Streptomyces are aerobic, Gram-positive, mycelia-forming soil bacteria, and are known to produce various kinds of antibiotics composed of many aromatic residues. $S$. maritimus possess a complex amino acid mod- ification pathway and can serve as a new platform microbe to produce aromatic building-block compounds. In this study, we carried out benzoate fermentation using $S$. maritimus. In order to enhance benzoate productivity using cellulose as the carbon source, we constructed endo-glucanase secreting S. maritimus. After 4 days of cultivation using glucose, cellobiose, or starch as a carbon source, the maximal level of benzoate reached 257, 337, and $460 \mathrm{mg} / \mathrm{l}$, respectively. $S$. maritimus expressed $\beta$-glucosidase and high amylase-retaining activity compared to those of $S$. lividans and $S$. coelicolor. In addition, for effective benzoate production from cellulosic materials, we constructed endo-glucanase-secreting S. maritimus. This transformant efficiently degraded the phosphoric acid swollen cellulose (PASC) and then produced $125 \mathrm{mg} / \mathrm{l}$ benzoate.

http://dx.doi.org/10.1016/j.nbt.2012.08.138

\section{Poster 1.2.07}

Establishing a high throughput method for medium optimization - a case study using Streptomyces lividans as host for production of heterologous protein

Stig Rattleff*, Jette Thykaer, Anna Eliasson Lantz

DTU Systems Biology, Technical University of Denmark

Actinomycetes are widely known for production of antibiotics, though as hosts for heterologous protein expression they show great potential which should be further developed. Streptomyces lividans is especially interesting due to very low endogenous protease activity and the capability to secrete proteins to the medium. As saprophyte it also has the ability to use a very diverse range of substrates including cellulose. Furthermore, a growing array of genetic tools has been developed, while sequencing and annotation is still to follow in the near future as various initiatives are in progress.

Medium composition can have great effect on the cellular performance, in particular on heterologous protein production. It is a parameter that can be adjusted regardless of GMO concerns or knowledge of genomic sequence. Optimizing medium composition can be labor intensive opening up for introducing automation.

In this study a potential high throughput method was tested for optimizing medium composition, with respect to nitrogen, to improve heterologous protein production in S. lividans, using mRFP as a model protein. A large number of nitrogen sources were tested in an initial, highly automated, screen. Subsequently the most promising candidates were tested in milliliter scale, followed by final verification in lab-scale fermentation. The method has the great advantage that the initial steps have a high degree of automation, which allows to retain a relatively high number of candidates. A further benefit of this approach is that substantial physiological knowledge is gained from the unsequenced model producer.

http://dx.doi.org/10.1016/j.nbt.2012.08.139 